\title{
Development of coding single nucleotide polymorphic markers in the pearl oyster Pinctada fucata based on next-generation sequencing and high-resolution melting analysis
}

\author{
S.G. Fan ${ }^{1}$, J.F. Wei ${ }^{1,2}$, Y.H. Guo ${ }^{1}$, G.J. Huang ${ }^{1}$ and D.H. Yu ${ }^{1}$ \\ ${ }^{1}$ Key Laboratory of South China Sea Fishery Resources Exploitation and \\ Utilization, Ministry of Agriculture, South China Sea Fisheries Research \\ Institute, Chinese Academy of Fishery Sciences, Guangzhou, China \\ ${ }^{2}$ College of Fisheries and Life Science, Shanghai Ocean University, Shanghai, \\ China \\ Corresponding author: D.H. Yu \\ E-mail: 18602058697@163.com
}

Genet. Mol. Res. 15 (4): gmr15049054

Received August 3, 2016

Accepted September 19, 2016

Published November 3, 2016

DOI http://dx.doi.org/10.4238/gmr15049054

Copyright (C) 2016 The Authors. This is an open-access article distributed under the terms of the Creative Commons Attribution ShareAlike (CC BY-SA) 4.0 License.

ABSTRACT. The pearl oyster Pinctada fucata is an important
commercial marine shellfish that is cultured for producing saltwater
pearls. In this study, 468 single nucleotide polymorphisms (SNPs)
were screened from P. fucata transcriptome data, and 119 polymorphic
SNPs were successfully isolated by a two-step small-amplicon high-
resolution melting assay. Of these, 88 were annotated with BLAST in
the Nr database and 90 were in the open reading frame, including 16
non-synonymous SNPs and 74 synonymous SNPs; 12 SNPs were in
the 3 '-untranslated region (UTR) and 1 was in the 5'-UTR. Twenty-five
SNPs were randomly chosen to test the genetic diversity of 40 wild

Genetics and Molecular Research 15 (4): gmr15049054 
individuals from Liusha Bay, China. All of the loci had two alleles. The observed and expected heterozygosities ranged from 0.0417 to 0.6042 and from 0.2945 to 0.5053 , respectively. Minor allele frequencies ranged from 0.1771 to 0.5000 , and the polymorphism information content ranged from 0.2516 to 0.3750 . These novel SNP markers can contribute to $P$. fucata genetics and breeding studies.

Key words: SNP; Pinctada fucata; Transcriptome sequencing; High-resolution melting

\section{INTRODUCTION}

The pearl oyster, Pinctada fucata, is an important commercial marine shellfish that is cultured for producing saltwater pearls in China, Japan, and Australia (Yu and $\mathrm{Chu}, 2006$ ). It is also an important animal model for investigating biomineralization (i.e., scientific, medical, and commercial applications) and evolutionary biology (Jones et al., 2013). Pearl quality has recently decreased in both China and Japan. One possible reason is that the growth performance of $P$. fucata is hampered by inbreeding during aquaculture (Wada and Komaru, 1996; Qiu et al., 2014).

Genetic markers are powerful genetics study tools, particularly for genetic mapping and trait improvement (Huang et al., 2014a). Because of their abundance, value, and efficiency, single nucleotide polymorphisms (SNPs) have become the most powerful marker system for genetic research (Gomez-Uchida et al., 2014). Compared to noncoding genomic markers, SNPs developed from functional genes may be responsible for traits of commercial interest in this species, such as growth, reproduction, and resistance (Gao et al., 2013; Klinbunga et al., 2015; Ranjan et al., 2015). Transcriptome sequencing with next-generation sequencing technologies could provide extensive resources for large-scale gene-associated SNP mining (Grabherr et al., 2011). High-resolution melting (HRM) has proven to be a simple, low-cost, and highly sensitive technique to detect SNPs, and to profile genetic variation within polymerase chain reaction (PCR) amplicons (Cui et al., 2013).

In this study, the genetic diversity and structure of a wild population of $P$. fucata from South China were examined. A total of 119 polymorphic SNPs from the transcriptome sequence were successfully isolated by HRM analysis, which can contribute to $P$. fucata genetics and breeding studies.

\section{MATERIAL AND METHODS}

\section{DNA extraction}

Forty-eight wild adult individuals of $P$. fucata (shell length, $3-4 \mathrm{~cm}$ ) were obtained from Liusha Bay, Zhanjiang, Guangdong province, China $\left(109^{\circ} 49^{\prime} \mathrm{E}, 20^{\circ} 26^{\prime} \mathrm{N}\right)$. Each adductor muscle was cut and stored in 95\% ethanol. Genomic DNA was extracted using a Marine Animals DNA Kit (Tiangen, China) according to the manufacturer specifications. DNA integrity and purity were determined by agarose gel $(1 \%)$ electrophoresis and spectrophotometry (NanoDrop $^{\mathrm{TM}}$ 2000; Thermo Fisher Scientific, USA).

Genetics and Molecular Research 15 (4): gmr15049054 


\section{Primer design}

A total of 468 putative SNPs with no other predicted SNPs in the 30-bp neighboring regions were randomly chosen from $P$. fucata transcriptome data ( $\mathrm{Yu} \mathrm{DH}$ and Fan $\mathrm{SG}$, unpublished data). The primers were designed by Primer Premier 5.0 (Premier Biosoft International, USA). Amplicon lengths ranged from 40 to $100 \mathrm{bp}$, primer lengths from 20 to $30 \mathrm{bp}$, the GC content was $40-60 \%$, and the melting temperatures were $50^{\circ}-60^{\circ} \mathrm{C}$. The sequence and amplicon size of primers were shown in Table 1. Two unblocked double-stranded oligonucleotides were used as high- and low-temperature internal controls to calibrate the temperature variation between reactions (Table 2) (Seipp et al., 2007). All of the primers were synthesized and purified by Sangon Biotech (Shanghai, China).

\section{Amplification of candidate SNPs}

PCR amplification was performed in a $25-\mu \mathrm{L}$ volume containing $1.25 \mathrm{U}$ rTaq polymerase (TaKaRa, Japan), 1X PCR buffer $\left(\mathrm{MgCl}_{2}\right), 0.2 \mathrm{mM}$ dNTPs, $0.2 \mu \mathrm{M}$ of each primer, and 20-50 ng genomic DNA. The PCR conditions were as follows: pre-incubation at $95^{\circ} \mathrm{C}$ for $5 \mathrm{~min}$, followed by 30 cycles at $94^{\circ} \mathrm{C}$ for $20 \mathrm{~s}, 55^{\circ} \mathrm{C}$ or $50^{\circ} \mathrm{C}$ for $30 \mathrm{~s}, 72^{\circ} \mathrm{C}$ for 30 $\mathrm{s}$, and a final extension at $72^{\circ} \mathrm{C}$ for $7 \mathrm{~min}$. All of the PCR products were verified by $8 \%$ nondenaturing polyacrylamide gel electrophoresis (PAGE). Only primer pairs that produced a clear target band on the gel were selected for subsequent HRM analysis.

\section{SNP validation and polymorphism detection by HRM analysis}

SNP genotyping was performed using the two-step HRM method described by Wang et al. (2013, 2015), with small modifications. Genomic DNA from eight $P$. fucata individuals was used as amplification templates. After PCR amplification, $8.9 \mu \mathrm{L}$ PCR product, $0.1 \mu \mathrm{L}$ of each internal control $(10 \mu \mathrm{M}), 0.7 \mu \mathrm{L}$ LC Green (Idaho Technology Inc., USA), and $20 \mu \mathrm{L}$ mineral oil (Sigma, USA) were added to BLK/WHT 96-well plates (Bio-Rad, USA). After centrifuging at $2000 \mathrm{~g} / \mathrm{min}$ for $30 \mathrm{~s}$, the mixture was denatured at $95^{\circ} \mathrm{C}$ for $10 \mathrm{~min}$ using a thermal cycler (Hamburg, Germany). A LightScanner ${ }^{\mathrm{TM}}$ instrument (Idaho Technology Inc., USA) was used for the HRM analysis. Fluorescence intensity data were collected over $55^{\circ}$ $98^{\circ} \mathrm{C}$ at a thermal transition rate of $0.1^{\circ} \mathrm{C} / \mathrm{s}$. The HRM system software was used to analyze the melt curve peaks and genotypes.

\section{Functional annotation}

All of the unigene-obtained polymorphic SNPs were BLASTx searched in the $\mathrm{Nr}$ database with an e-value cutoff of 1e-5. SNP positions were determined using open reading frame (ORF) Finder (https://www.ncbi.nlm.nih.gov/orffinder/). SNP mutation type was analyzed using Primer Premier 5.0.

\section{Genetic diversity}

Twenty-five polymorphic loci were randomly chosen to examine the genetic diversity of a wild population of $P$. fucata from Liusha Bay.

Genetics and Molecular Research 15 (4): gmr15049054 
S.G. Fan et al.

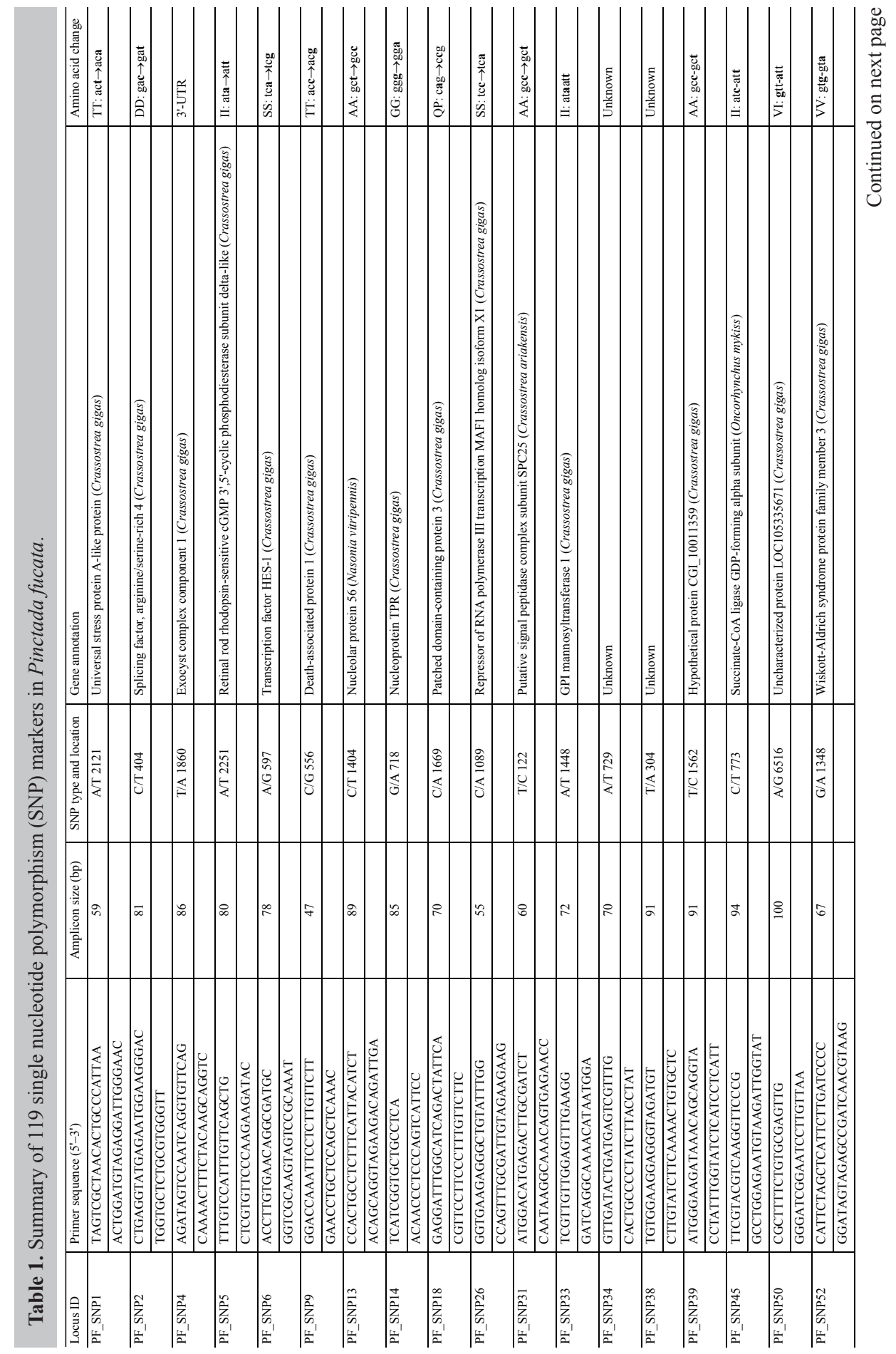

Genetics and Molecular Research 15 (4): gmr15049054 
Novel coding SNP markers in Pinctada fucata

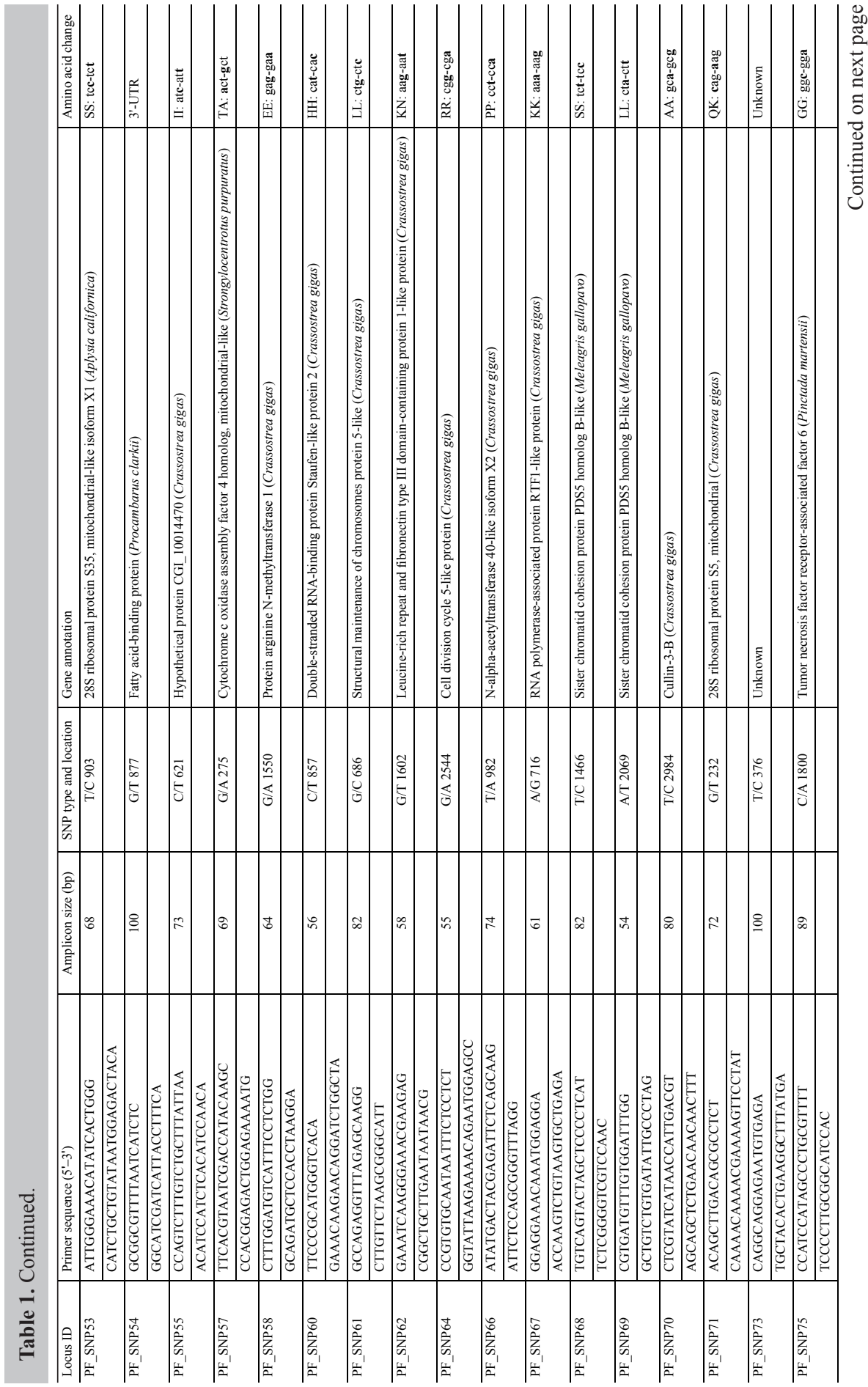

Genetics and Molecular Research 15 (4): gmr15049054 
S.G. Fan et al.

6

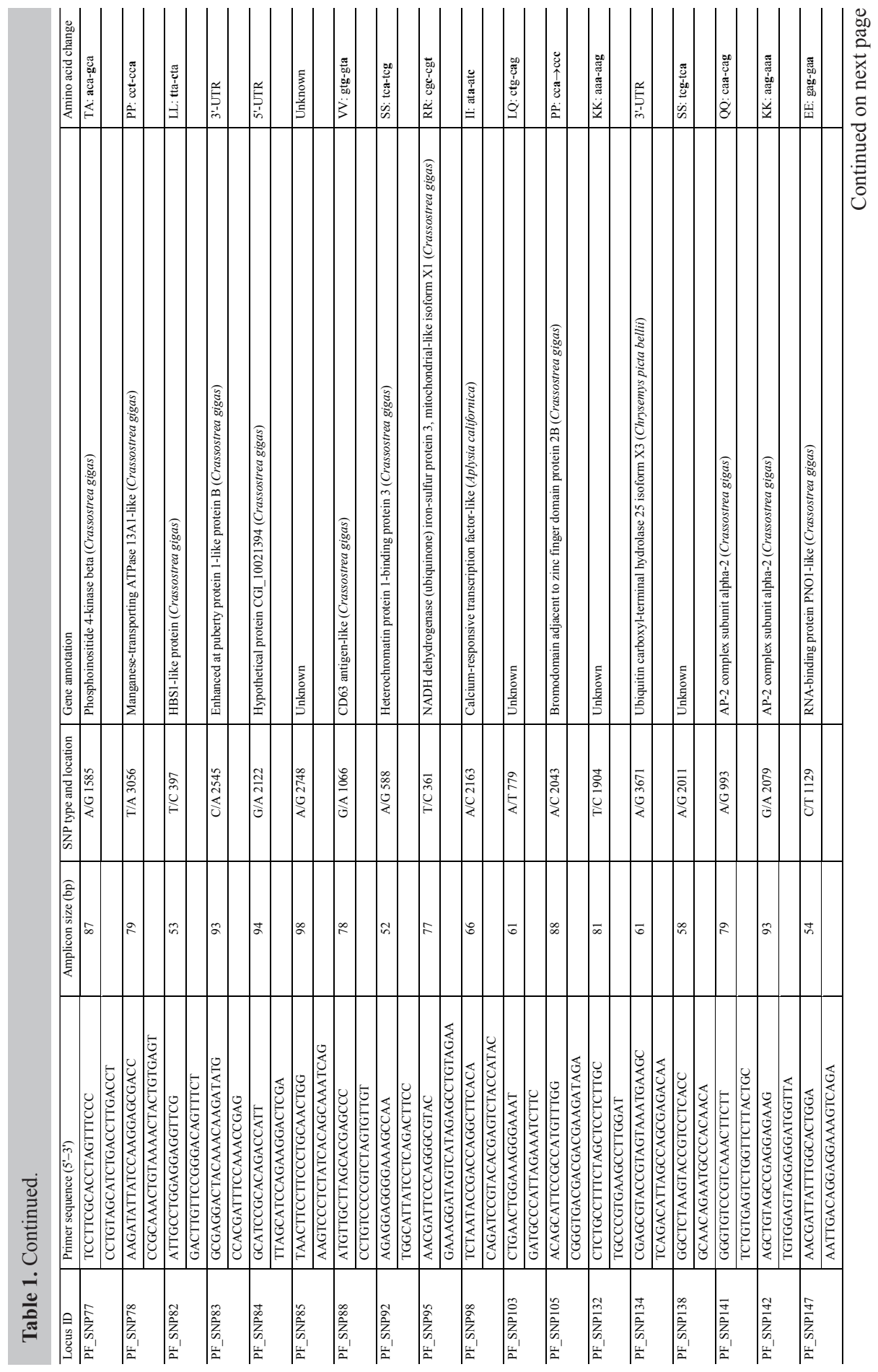

Genetics and Molecular Research 15 (4): gmr15049054 
Novel coding SNP markers in Pinctada fucata

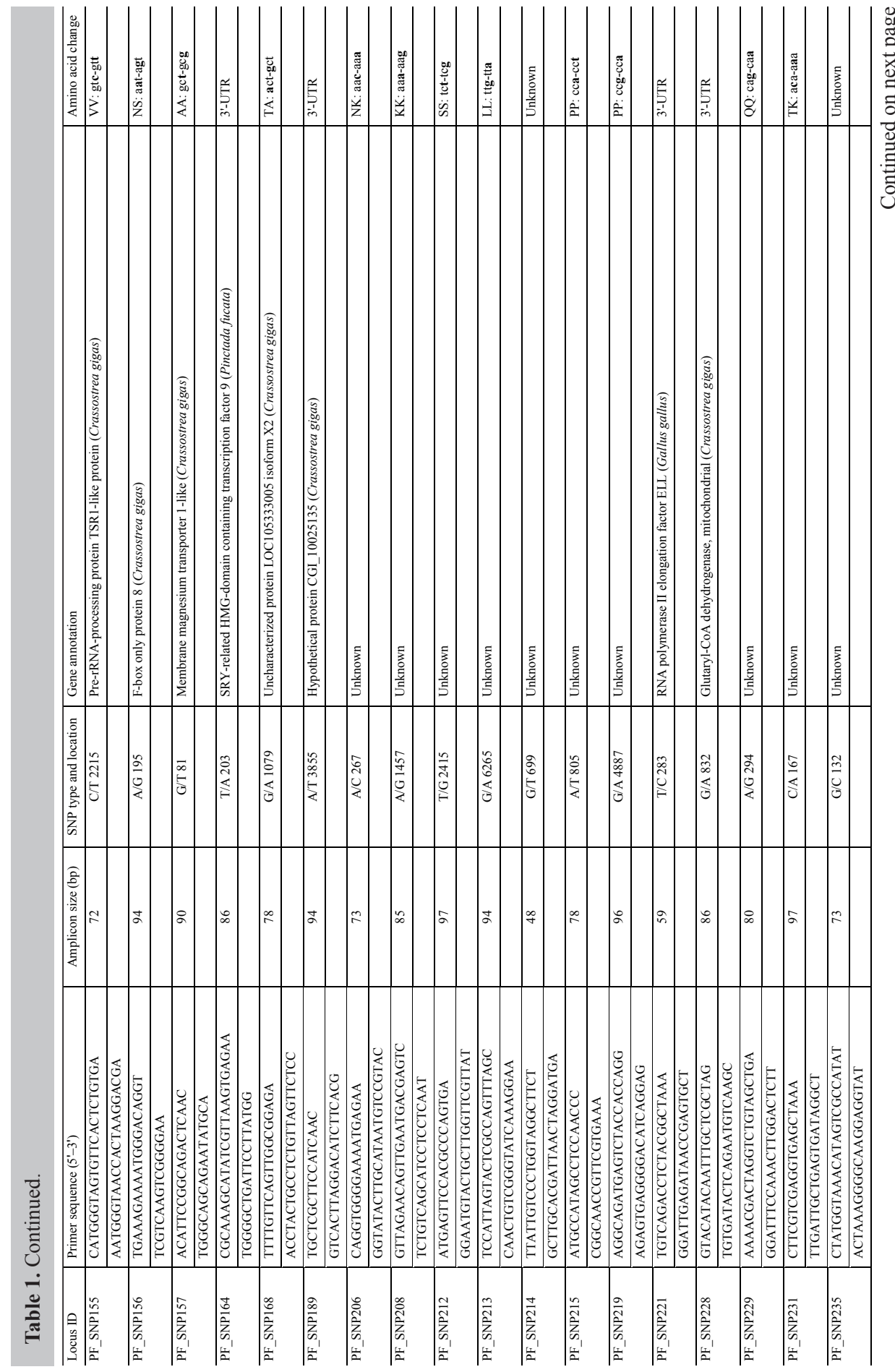

Genetics and Molecular Research 15 (4): gmr15049054 
S.G. Fan et al.

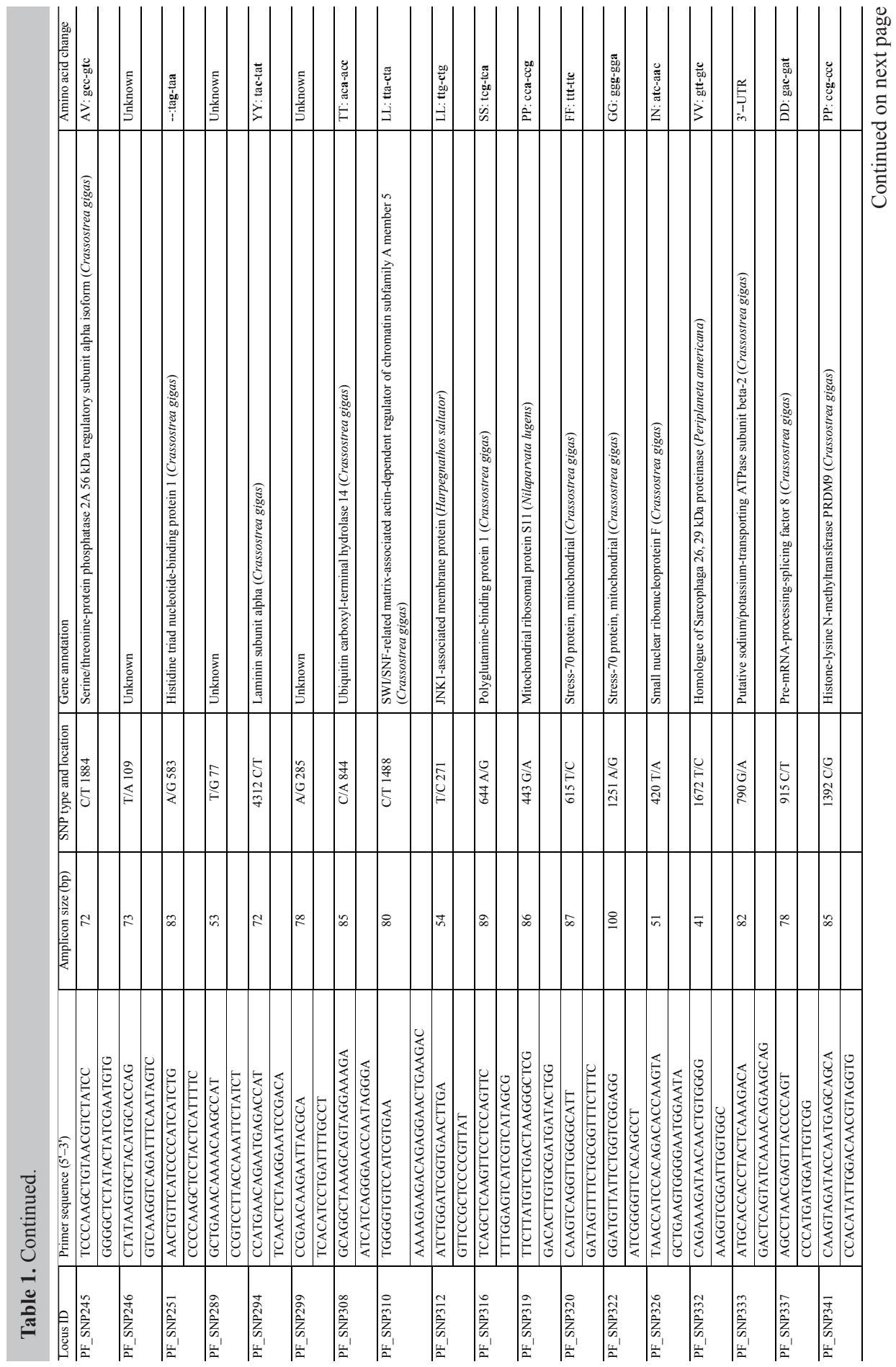

Genetics and Molecular Research 15 (4): gmr15049054 


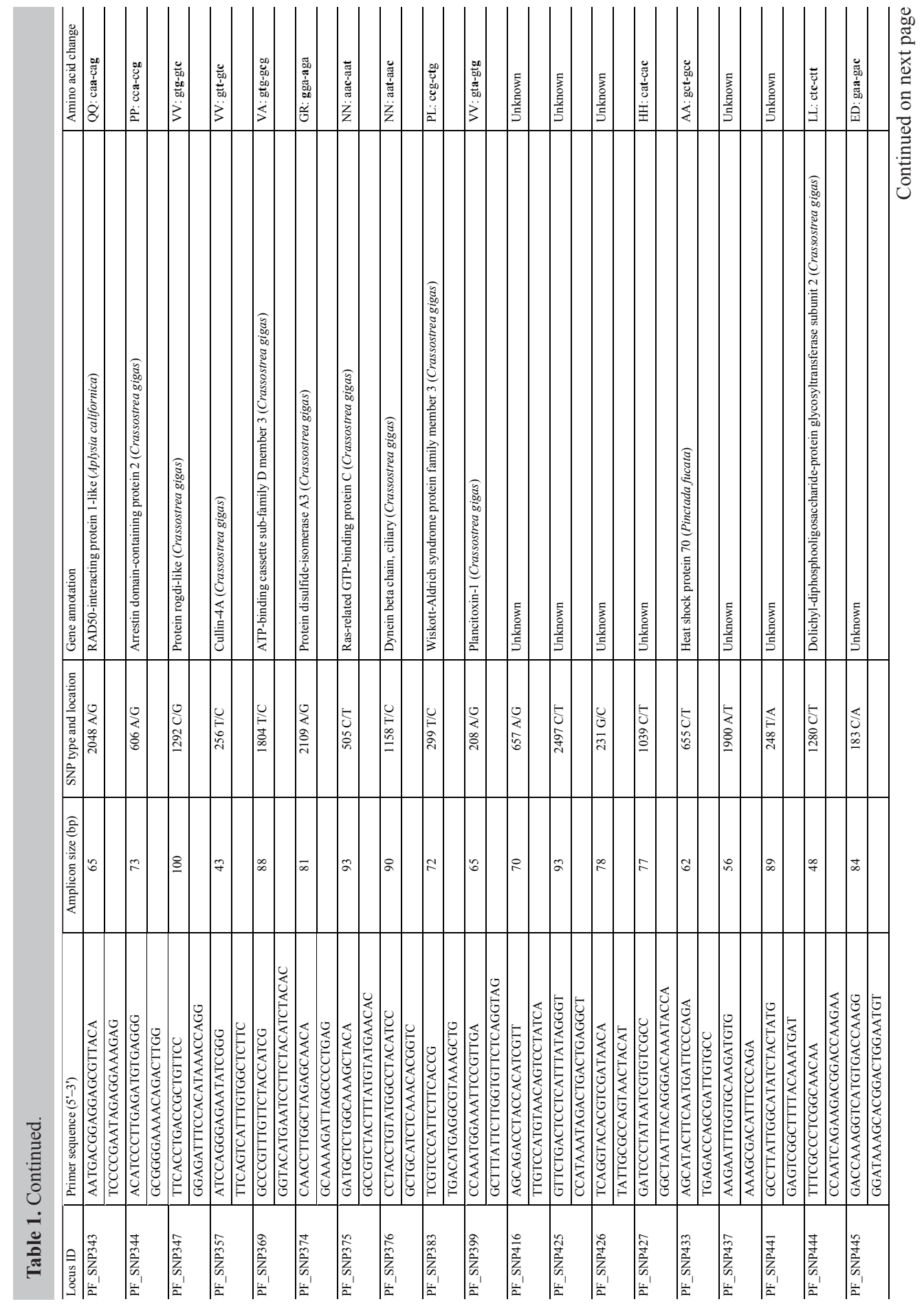

Genetics and Molecular Research 15 (4): gmr15049054 


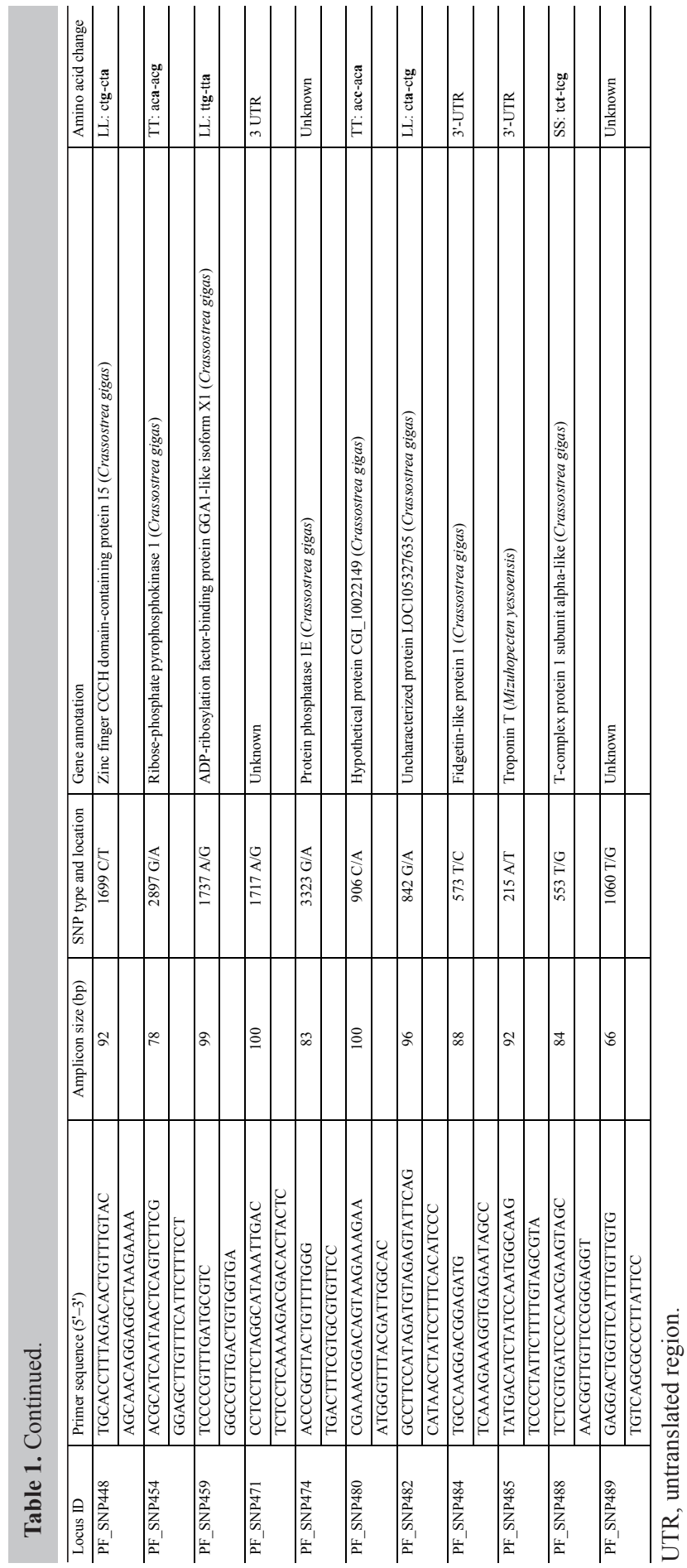

Genetics and Molecular Research 15 (4): gmr15049054 
The PCR process and HRM analysis were performed as described above. The number of alleles per locus, effective number of alleles, observed heterozygosity $\left(H_{\mathrm{O}}\right)$, expected heterozygosity $\left(H_{\mathrm{E}}\right)$, and minor allele frequency (MAF) were assessed using the POPGENE 32 software (Yeh et al., 2000), and the polymorphism information content (PIC) was calculated using the PICcalc online software (Nagy et al., 2012).

Table 2. Sequences and predicted and observed melting temperatures of internal temperature controls.

\begin{tabular}{l|l|c|c}
\hline Name & Forward/reverse sequence $\left(5^{\prime}-3^{\prime}\right)^{*}$ & Predicted temperature $\left({ }^{\circ} \mathrm{C}\right)$ & Observed temperature $\left({ }^{\circ} \mathrm{C}\right)$ \\
\hline High-temperature sequences & $\begin{array}{l}\text { F:GCGGTCAGTCGGCCTAGCGGTAGCCAGCTG } \\
\text { CGGCACTGCGTGACGCTCAG }\end{array}$ & 90.02 & \\
\cline { 2 - 2 } & $\begin{array}{l}\text { R:CTGAGCGTCACGCAGTGCCGCAGCTGGCTACCGC } \\
\text { TAGGCCGACTGACCGC }\end{array}$ & & \\
\hline Low-temperature sequences & $\begin{array}{l}\text { F:ATCGTGATTCTATAGTTATCTAAGTAGTTGGCAT } \\
\text { TAATAATTTCATTTT }\end{array}$ & 68.5 & \\
\cline { 1 - 2 } & $\begin{array}{l}\text { R:AAAATGAAATTATTAATGCCAACTACTTAGATAA } \\
\text { CTATAGAAATCACGAT }\end{array}$ & & \\
\hline
\end{tabular}

*All of the sequences were blocked with a phosphate at the 3 '-end.

\section{RESULTS AND DISCUSSION}

Small-amplicon HRM assays (SA-HRMAs) provide a rapid, inexpensive, and highthroughput closed-tube method for genotyping (Smith et al., 2010). To ensure SA-HRMA accuracy, we used three criteria: 1) SA-HRMA amplicons were no more than $100 \mathrm{bp}$ long, which ensured that homozygous genotypes of alleles were easily distinguished; 2) only one SNP was present in each amplicon; and 3) high- and low-temperature controls were added for each amplicon, which decreased melting temperature variations attributable to the instrument or solution chemistry and corrected melting profiles (Seipp et al., 2007). An improved twostep SA-HRM method for Pacific oyster (Crassostrea gigas) SNP validation has been shown to be efficient and economical (Wang et al., 2013, 2015), and this method was successfully used to validate 119 polymorphic SNPs from P. fucata transcriptome data, demonstrating that it is feasible in shellfish.

A subset of 468 primers was randomly designed to validate the SNP predictions. No amplification products were seen in 66 sets of primers, and introns were found in genomic DNA but not the transcriptome. If the primer flanked, or was located in, an intron, the intervening fragment could not be amplified. A total of 173 sets of primers amplified multiple bands, and 229 amplified a clear target band on PAGE. The ratio of primer screening was $48.93 \%$, which is higher than previously reported values of $41.67 \%$ (Zhang et al., 2015) and 28.10\% (Huang et al., 2014b).

All of the SNP-containing unigenes were annotated with the corresponding top best BLASTx hits, and 88 SNPs were annotated though BLASTx in the Nr database (Table 1). Of these, heat-shock protein 70 is expressed in response to changes in temperature, bacterial infection, or $\mathrm{pH}$. Its main function is to promote protein folding, and thereby prevent the cellular accumulation of non-native proteins (Mymrikov et al., 2011). F-box proteins are an expanding family of eukaryotic proteins, characterized by an approximately 40 -aminoacid motif (Cenciarelli et al., 1999). F-box proteins were first characterized as components of SCF ubiquitin-ligase complexes, in which they bind substrates for ubiquitin-mediated proteolysis (Kipreos and Pagano, 2000). Fatty acid-binding proteins participate in lipid uptake, transport, and homeostasis (Bayir et al., 2015). Sox9 (SRY-related HMG-domaincontaining transcription factor 9) and cullin-3-B play important roles in testis development (Bergstrom et al., 2000; Lu et al., 2005). Among the 229 well-amplified SNPs, 119 (51.97\%)

Genetics and Molecular Research 15 (4): gmr15049054 
were polymorphic in 8 P. fucata individuals, according to the SA-HRMA (Table 1). Seventyfive SNPs were genotyped as transitions, including $40 \mathrm{~A} / \mathrm{G}$ and $35 \mathrm{C} / \mathrm{T}$, and 44 were genotyped as the transversions $11 \mathrm{~A} / \mathrm{C}, 18 \mathrm{~A} / \mathrm{T}, 6 \mathrm{C} / \mathrm{G}$, and $9 \mathrm{G} / \mathrm{T}$. According to ORF Finder, $90 \mathrm{SNPs}$ were located in the ORF, including 16 non-synonymous SNPs and 74 synonymous SNPs; 12 SNPs were located in the 3'-untranslated region (UTR), and 1 was located in the 5'-UTR. SNPs within a coding sequence may change a protein's amino acid sequence and structure, thus influencing its functions (Gao et al., 2014; An et al., 2015). The post-transcriptional regulation of gene expression is crucial for many physiological processes. SNPs within UTRs may have consequences for gene splicing, expression, and regulation (Malodobra-Mazur et al., 2016; $\mathrm{Xu}$ et al., 2016). SNPs developed from functional genes may be used in association studies, which could genetically improve species. For example, some SNPs are associated with growth traits in the pearl oyster (Shi et al., 2014), and SNPs screened from the myostatin gene are associated with growth traits in the scallop and carp (Wang et al., 2010; Guo et al., 2011; Liu et al., 2012; Sun et al., 2012). All of the annotation unigenes and their SNPs may be useful for studying the commercial traits of $P$. fucata, such as growth, resistance, and reproduction.

Twenty-five SNPs were successfully used to test the genetic diversity of 40 wild $P$. fucata from Liusha Bay, China (Table 3). All of the SNP loci had intermediate PIC values $(0.25<\mathrm{PIC}<0.5)$, with a mean of 0.3336 . The $H_{\mathrm{O}}$ was $0.0417-0.6042$ and the $H_{\mathrm{E}}$ was 0.2945 0.5053 . Li et al. (2016) used SNP loci to analyze the genetic diversity of $P$. fucata individuals from three families, and obtained PIC values of 0.2435, 0.2479, and 0.2977. Huang et al. (2014a) used SNP loci to study the genetic diversity of a wild $P$. fucata population in Shenzhen, China, and reported MAF, $H_{\mathrm{O}}$, and $H_{\mathrm{E}}$ values of $0.0642-0.4375,0.1282-0.4872$, and 0.1215 0.4984 , respectively. These findings indicate that the Liusha population genetic diversity is higher than that in culture or in the Shenzhen population.

Table 3. Summary of 25 single nucleotide polymorphisms in wild Pinctada fucata individuals.

\begin{tabular}{|c|c|c|c|c|c|}
\hline Locus & $N_{\mathrm{E}}$ & $H_{\mathrm{O}}$ & $H_{\mathrm{E}}$ & MAF & PIC \\
\hline PF_SNP1 & 1.7041 & 0.5000 & 0.4175 & 0.2917 & 0.3270 \\
\hline PF_SNP9 & 1.9321 & 0.6042 & 0.4875 & 0.4062 & 0.3668 \\
\hline PF_SNP18 & 1.9965 & 0.5417 & 0.5044 & 0.4792 & 0.3746 \\
\hline PF_SNP31 & 1.8221 & 0.3125 & 0.4559 & 0.3438 & 0.3481 \\
\hline PF_SNP33 & 1.7771 & 0.1458 & 0.4419 & 0.3229 & 0.3405 \\
\hline PF_SNP52 & 1.9459 & 0.4167 & 0.4912 & 0.4167 & 0.3685 \\
\hline PF_SNP55 & 1.6265 & 0.3542 & 0.3893 & 0.2604 & 0.3108 \\
\hline PF_SNP58 & 1.9991 & 0.6042 & 0.5050 & 0.4896 & 0.3749 \\
\hline PF_SNP64 & 1.4113 & 0.2292 & 0.2945 & 0.1771 & 0.2516 \\
\hline PF_SNP67 & 1.9584 & 0.4792 & 0.4945 & 0.4271 & 0.3700 \\
\hline PF_SNP68 & 1.9965 & 0.2500 & 0.5044 & 0.4792 & 0.3746 \\
\hline PF_SNP69 & 1.8824 & 0.4583 & 0.4737 & 0.3750 & 0.3589 \\
\hline PF_SNP70 & 2.0000 & 0.4583 & 0.5053 & 0.5000 & 0.3750 \\
\hline PF_SNP71 & 1.5463 & 0.2917 & 0.3570 & 0.2292 & 0.2915 \\
\hline PF_SNP73 & 1.8000 & 0.4583 & 0.4491 & 0.3333 & 0.3444 \\
\hline PF_SNP75 & 1.8633 & 0.1875 & 0.4682 & 0.3646 & 0.3546 \\
\hline PF_SNP77 & 1.6000 & 0.2500 & 0.3789 & 0.2500 & 0.3047 \\
\hline PF_SNP82 & 1.9692 & 0.5000 & 0.4974 & 0.4375 & 0.3714 \\
\hline PF_SNP83 & 1.8432 & 0.0417 & 0.4623 & 0.3542 & 0.3515 \\
\hline PF_SNP84 & 1.5463 & 0.2500 & 0.3570 & 0.2292 & 0.2915 \\
\hline PF_SNP88 & 1.4922 & 0.1667 & 0.3333 & 0.2083 & 0.2768 \\
\hline PF_SNP92 & 1.7041 & 0.5833 & 0.4175 & 0.2917 & 0.3270 \\
\hline PF_SNP95 & 1.5463 & 0.2917 & 0.3570 & 0.2292 & 0.2915 \\
\hline PF_SNP98 & 1.4922 & 0.1667 & 0.3333 & 0.2083 & 0.2768 \\
\hline PF_SNP103 & 1.6528 & 0.4167 & 0.3991 & 0.2708 & 0.3165 \\
\hline Average & 1.7643 & 0.3583 & 0.4310 & 0.3350 & 0.3336 \\
\hline
\end{tabular}

$H_{\mathrm{E}}$, expected heterozygosity; $H_{\mathrm{O}}$, observed heterozygosity; MAF, minor allele frequency; $N_{\mathrm{E}}$, effective number of alleles; PIC, polymorphism information content.

Genetics and Molecular Research 15 (4): gmr15049054 
HRM technology can directly distinguish between different genotypes based on melting peak profiles (Smith et al., 2010). Figure 1a and b show the melting curve analyses of PF_SNP9 and PF_SNP98, respectively.
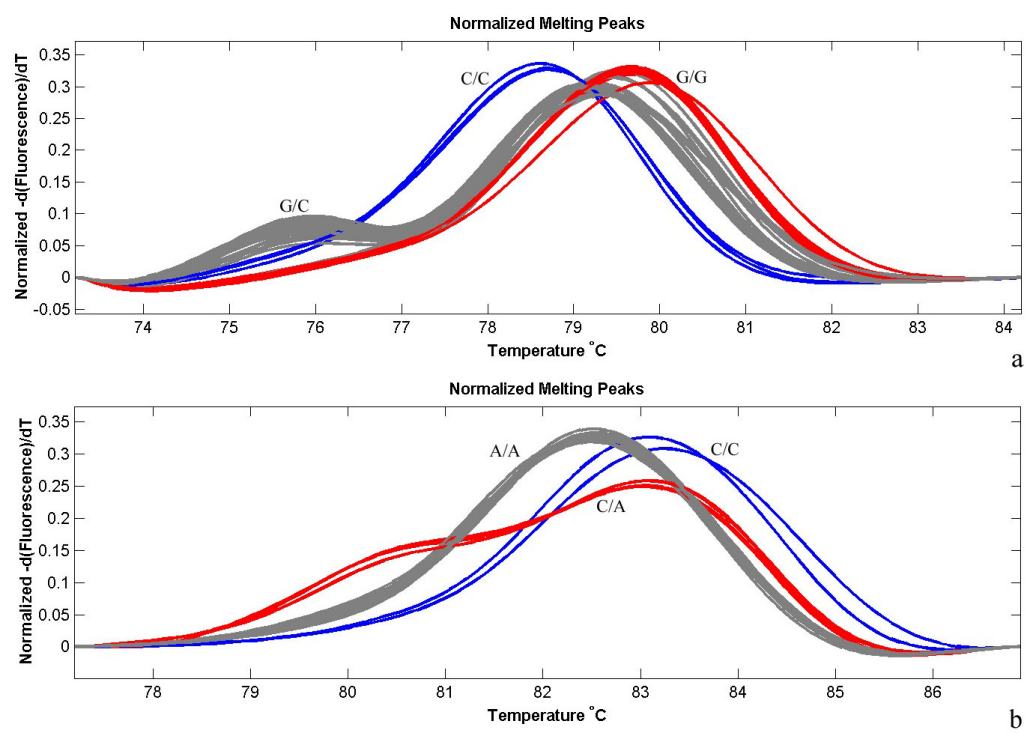

Figure 1. Genotyping results using high-resolution melting with a small amplicon. a. PF_SNP9, homozygotes (GG and CC) and heterozygotes (GC) are represented by red, blue, and gray curves, respectively. b. PF_SNP98, homozygotes (AA and $\mathrm{CC}$ ) and heterozygotes (CA) are represented by gray, blue, and red curves, respectively.

In conclusion, 119 polymorphic SNPs were successfully isolated by SA-HRMA, thus contributing to our understanding of $P$. fucata genetics and breeding.

\section{Conflicts of interest}

The authors declare no conflict of interest.

\section{ACKNOWLEDGMENTS}

Research supported by the PhD Start-Up Fund of Natural Science Foundation of Guangdong Province (\#2014A030310237), the Natural Science Foundation Program of Hainan Province (\#20154180), the Basic Scientific Research Fund for the Central Institutes of Public Welfare (South China Sea Fisheries Research Institute, \#2014TS08), the Special Fund for Marine Fisheries Research and Extension of Guangdong Province (\#A201401A07, \#Z2015010), the National Natural Science Foundation of China (\#31372525), and the Earmarked Fund for China Agriculture Research System (\#CARS-48).

\section{REFERENCES}

An XP, Song YX, Hou JX, Han P, et al. (2015). Mutations in the MTHFR gene and their associations with milk production traits in dairy goats. Small Rumin. Res. 130: 76-80. http://dx.doi.org/10.1016/j.smallrumres.2015.06.008

Genetics and Molecular Research 15 (4): gmr15049054 
Bayır M, Bayır A and Wright JM (2015). Divergent spatial regulation of duplicated fatty acid-binding protein (fabp) genes in rainbow trout (Oncorhynchus mykiss). Comp. Biochem. Physiol. Part D Genomics Proteomics 14: 26-32. http:// dx.doi.org/10.1016/j.cbd.2015.02.002

Bergstrom DE, Young M, Albrecht KH and Eicher EM (2000). Related function of mouse SOX3, SOX9, and SRY HMG domains assayed by male sex determination. Genesis 28: 111-124. http://dx.doi.org/10.1002/1526968X(200011/12)28:3/4<111::AID-GENE40>3.0.CO $; 2-5$

Cenciarelli C, Chiaur DS, Guardavaccaro D, Parks W, et al. (1999). Identification of a family of human F-box proteins. Curr. Biol. 9: 1177-1179. http://dx.doi.org/10.1016/S0960-9822(00)80020-2

Cui G, Zhang L, Xu Y, Cianflone K, et al. (2013). Development of a high resolution melting method for genotyping of risk HLA-DQA1 and PLA2R1 alleles and ethnic distribution of these risk alleles. Gene 514: 125-130. http://dx.doi. org/10.1016/j.gene.2012.11.004

Gao L, Chen M, Chang Y, Ji N, et al. (2013). Development of SNP markers associated with defense mechanism of sea cucumber, Apostichopus japonicas. Conserv. Genet. Resour. 5: 587-591. http://dx.doi.org/10.1007/s12686-013$\underline{9858-Z}$

Gao Q, Ju Z, Zhang Y, Huang J, et al. (2014). Association of TNP2 gene polymorphisms of the bta-miR-154 target site with the semen quality traits of Chinese Holstein bulls. PLoS One 9: e84355. http://dx.doi.org/10.1371/journal. pone. 0084355

Gomez-Uchida D, Seeb L, Warheit K, McKinney G, et al. (2014). Deep sequencing of the transcriptome and mining of single nucleotide polymorphisms (SNPs) provide genomic resources for applied studies in Chinook salmon (Oncorhynchus tshawytscha). Conserv. Genet. Resour. 6: 807-811. http://dx.doi.org/10.1007/s12686-014-0235-3

Grabherr MG, Haas BJ, Yassour M, Levin JZ, et al. (2011). Full-length transcriptome assembly from RNA-Seq data without a reference genome. Nat. Biotechnol. 29: 644-652.http://dx.doi.org/10.1038/nbt.1883

Guo L, Li L, Zhang S, Guo X, et al. (2011). Novel polymorphisms in the myostatin gene and their association with growth traits in a variety of bay scallop, Argopecten irradians. Anim. Genet. 42: 339-340. http://dx.doi.org/10.1111/j.13652052.2011.02172.X

Huang X, Wu S, Guan Y, Li Y, et al. (2014a). Identification of sixteen single-nucleotide polymorphism markers in the pearl oyster, Pinctada fucata, for population genetic structure analysis. J. Genet. 93: e1-e4.

Huang J, Zhang Y, Li J and Yu Z (2014b). Development of SNP markers in Crassostrea hongkongensis based on the next-generation sequencing and high resolution melting analysis. Conserv. Genet. Resour. 6: 559-562. http://dx.doi. org/10.1007/s12686-014-0218-4

Jones DB, Jerry DR, Forêt S, Konovalov DA, et al. (2013). Genome-wide SNP validation and mantle tissue transcriptome analysis in the silver-lipped pearl oyster, Pinctada maxima. Mar. Biotechnol. (NY) 15: 647-658. http://dx.doi. org/10.1007/s10126-013-9514-3

Kipreos ET and Pagano M (2000). The F-box protein family. Genome Biol. 1: REVIEWS3002.

Klinbunga S, Sittikankaew K, Jantee N, Prakopphet S, et al. (2015). Expression levels of vitellogenin receptor (Vtgr) during ovarian development and association between its single nucleotide polymorphisms (SNPs) and reproductionrelated parameters of the giant tiger shrimp Penaeus monodon. Aquaculture 435: 18-27. http://dx.doi.org/10.1016/j. aquaculture.2014.09.013

Li Y, Liu W, Lin J and He M (2016). Development of SNP markers in Pinctada fucata and its application for family genetic analysis. Mar. Sci. Bull. 35: 96-102.

Liu L, Yu X and Tong J (2012). Molecular characterization of myostatin (MSTN) gene and association analysis with growth traits in the bighead carp (Aristichthys nobilis). Mol. Biol. Rep. 39: 9211-9221. http://dx.doi.org/10.1007/ $\underline{\text { s11033-012-1794-6 }}$

Lu L, Zhou ZM, Huang XY, Xu M, et al. (2005). Identification and characterization of cul-3b, a novel hominine CUL-3 transcript variant. Asian J. Androl. 7: 205-211. http://dx.doi.org/10.1111/j.1745-7262.2005.00024.x

Malodobra-Mazur M, Bednarska-Chabowska D, Olewinski R, Chmielecki Z, et al. (2016). Single nucleotide polymorphisms in $5 \phi$-UTR of the $S L C 2 A 4$ gene regulate solute carrier family 2 member 4 gene expression in visceral adipose tissue. Gene 576: 499-504.http://dx.doi.org/10.1016/j.gene.2015.10.067

Mymrikov EV, Seit-Nebi AS and Gusev NB (2011). Large potentials of small heat shock proteins. Physiol. Rev. 91: 1123 1159. http://dx.doi.org/10.1152/physrev.00023.2010

Nagy S, Poczai P, Cernák I, Gorji AM, et al. (2012). PICcalc: an online program to calculate polymorphic information content for molecular genetic studies. Biochem. Genet. 50: 670-672. http://dx.doi.org/10.1007/s10528-012-9509-1

Qiu Y, Lu H, Zhu JT, Chen XF, et al. (2014). Characterization of novel EST-SSR markers and their correlations with growth and nacreous secretion traits in the pearl oyster Pinctada martensii (Dunker). Aquaculture 420: S92-S97. http://dx.doi.org/10.1016/j.aquaculture.2013.09.040

Genetics and Molecular Research 15 (4): gmr15049054 
Ranjan S, Bhushan B, Panigrahi M, Kumar A, et al. (2015). Association and expression analysis of single nucleotide polymorphisms of partial tumor necrosis factor alpha gene with mastitis in crossbred cattle. Anim. Biotechnol. 26: 98-104. http://dx.doi.org/10.1080/10495398.2014.929582

Seipp MT, Durtschi JD, Liew MA, Williams J, et al. (2007). Unlabeled oligonucleotides as internal temperature controls for genotyping by amplicon melting. J. Mol. Diagn. 9: 284-289. http://dx.doi.org/10.2353/jmoldx.2007.060136

Shi Y, Wang S, Gu Z, Lv J, et al. (2014). High-density single nucleotide polymorphisms linkage and quantitative trait locus mapping of the pearl oyster, Pinctada fucata martensii Dunker. Aquaculture 434: 376-384. http://dx.doi. org/10.1016/j.aquaculture.2014.08.044

Smith BL, Lu CP and Alvarado Bremer JR (2010). High-resolution melting analysis (HRMA): a highly sensitive inexpensive genotyping alternative for population studies. Mol. Ecol. Resour. 10: 193-196. http://dx.doi.org/10.1111/ j.1755-0998.2009.02726.x

Sun Y, Yu X and Tong J (2012). Polymorphisms in Myostatin Gene and associations with growth traits in the common carp (Cyprinus carpio L.). Int. J. Mol. Sci. 13: 14956-14961.http://dx.doi.org/10.3390/ijms131114956

Wada KT and Komaru A (1996). Color and weight of pearls produced by grafting the mantle tissue from a selected population for white shell color of the Japanese pearl oyster Pinctada fucata martensii (Dunker). Aquaculture 142: 25-32. http://dx.doi.org/10.1016/0044-8486(95)01242-7

Wang J, Qi H, Li L and Zhang G (2013). Two-step high-resolution melting method for SNP validation in the highly polymorphic Crassostrea gigas genome. Southwest Chin. J. Agr. Sci 26: 1699-1704.

Wang J, Qi H, Li L, Que H, et al. (2015). Discovery and validation of genic single nucleotide polymorphisms in the Pacific oyster Crassostrea gigas. Mol. Ecol. Resour. 15: 123-135. http://dx.doi.org/10.1111/1755-0998.12278

Wang X, Meng X, Song B, Qiu X, et al. (2010). SNPs in the myostatin gene of the mollusk Chlamys farreri: association with growth traits. Comp. Biochem. Physiol. B Biochem. Mol. Biol. 155: 327-330. http://dx.doi.org/10.1016/j. cbpb.2009.12.001

Xu Z, Tang L, Li Y, Ge J, et al. (2016). Identification of SNPs in the 5'-flanking region and 3'-UTR of the MIH gene and their association with precocity of the Chinese mitten crab Eriocheir sinensis. Aquacult. Res. 47: 992-1000. http:// dx.doi.org/10.1111/are.12559

Yeh FC, Yang R, Boyle TJ, Ye Z, et al. (2000). POPGENE 32, Microsoft windows based freeware for population genetic analysis. Molecular Biology and Biotechnology Centre, University of Alberta, Edmonton, Canada.

$\mathrm{Yu}$ DH and Chu KH (2006). Genetic variation in wild and cultured populations of the pearl oyster Pinctada fucata from southern China. Aquaculture 258: 220-227. http://dx.doi.org/10.1016/j.aquaculture.2006.03.024

Zhang N, Ma Z, Zhang D, Guo H, et al. (2015). Characterization of 25 single nucleotide polymorphism markers in the pearl oyster Pinctada martensii (Dunker). Conserv. Genet. Resour. 7: 831-835. http://dx.doi.org/10.1007/s12686$\underline{015-0503-\mathrm{X}}$

Genetics and Molecular Research 15 (4): gmr15049054 